\title{
Radiocarbon chronology of glacial lake sediments in the Retezat Mts (South Carpathians, Romania): a window to Late Glacial and Holocene climatic and paleoenvironmental changes
}

\author{
Enikő K. Magyari* \\ Research Group for Paleontology \\ Hungarian Academy of Sciences \\ Hungarian Natural History Museum, Budapest \\ Krisztina Buczkó \\ Hungarian Natural History Museum, Budapest
}

Péter László

Department of Physical Geography

Eötvös University, Budapest

Miklós Bálint

Biodiversität und Klima Forschungszentrum (BiK-F)

Frankfurt am Main, Germany

\author{
Mihály Braun \\ Department of Inorganic and Analytical Chemistry \\ University of Debrecen, Debrecen \\ Zoltán Kern \\ Institute for Geochemical Research \\ Hungarian Academy of Sciences, Budapest \\ Katalin Hubay \\ Department of Inorganic and Analytical Chemistry \\ University of Debrecen, Debrecen
}

As a first piece in a series of Late Quaternary paleoecological studies on the glacial lake sediments of the Retezat Mountains, this study discusses radiocarbon chronology and sediment accumulation rate changes in two sediment profiles in relation to lithostratigraphy, organic content, biogenic silica and major pollenstratigraphic changes. A total of 25 radiocarbon dates were obtained from sediments of two lakes, Lake Brazi (TDB-1; 1740 m a.s.l.) and Lake Gales (Gales-3; 1990 m a.s.l.). Age-depth modeling was performed on TDB-1 using calibrated age ranges from BCal and various curve-fitting methods in psimpoll. Our results suggest that sediment accumulation began between 15,124-15,755 cal yr BP in both lakes and was continuous throughout the Late Glacial and Holocene. We demonstrated that local ecosystem productivity showed delayed response to Late Glacial and Early Holocene climatic changes in the subalpine and alpine zones most likely attributable to the cooling effect of remnant glaciers and meltwater input. However, regional vegetation response was without time lag and indicated forestation and warming at 14,450 and 11,550 cal yr BP, and cooling at ca. 12,800 cal yr BP. In the Holocene one major shift was detected, starting around $6300 \mathrm{cal}$ yr BP and culminating around $5200 \mathrm{cal}$ yr BP. The various proxies suggested summer cooling, shorter duration of the winter ice-cover season and/or increasing size of the water body, probably in response to increasing available moisture.

Addresses: E. K. Magyari: H-1476 Budapest, P.O. Box 222, Hungary

M. Braun, K. Hubay: H-4010 Debrecen, P.O. Box 21, Hungary

K. Buczkó: H-1431 Budapest, P.O. Box 137, Hungary

P. László: H-1117 Budapest, Pázmány P. st. 1/c, Hungary

Z. Kern: H-1112 Budapest, Budaörsi út 45, Hungary

M. Bálint: Senckenberganlage 25, D-60325 Frankfurt am Main, Germany

Received: July 15, 2010; accepted: September 20, 2010

*Corresponding author: E-mail: magyari@bot.nhmus.hu 
Key words: Late Glacial, radiocarbon dating, loss-on-ignition, pollen, glacial lake sediments, rapid climate change

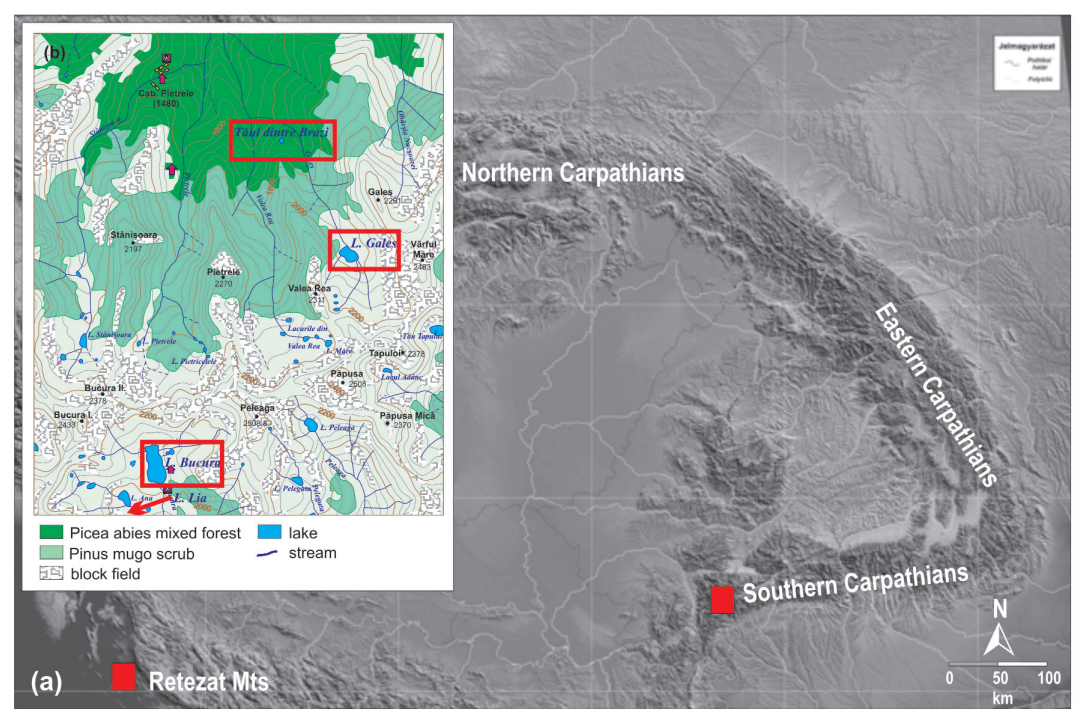

Fig. 1

Maps of East-Central Europe (a) and the Retezat Mountains (b) showing the location of Lake Brazi (1740 m a.s.l.), Lake Gales (1990 m a.s.l.) and two other lakes sampled on the southern slopes. Major altitudinal vegetation zones are also displayed and color-coded

\section{Introduction}

The highest peaks in the Romanian Carpathians are located in the west-east trending Southern Carpathians (Fig. 1). These peaks constituted the major areas of ice accumulation during the Pleistocene glaciations (Urdea 2000, 2004; Reuther et al. 2007). As a consequence, glacial landforms and lakes are abundant in these mountains, particularly in the southwestern high mountain range, the Retezat (Figs 1 and 2). The sediment accumulated in these lakes offers a unique possibility to study vegetation dynamics, soil changes and aquatic responses to climate change following glacial retreat. The usefulness of such paleoecological studies has amply been demonstrated in the Alps, where dozens of glacial lakes were studied to establish, inter alia, Late Glacial and Holocene tree line oscillations and soil development (e.g. Lotter and Birks 2003; Tinner and Theurillat 2003; Vescovi et al. 2007; Kaltenrieder et al. 2009; Ilyashuk et al. 2009). Despite the abundance of glacial lakes in the South Carpathians, similar analyses have yet to be carried 


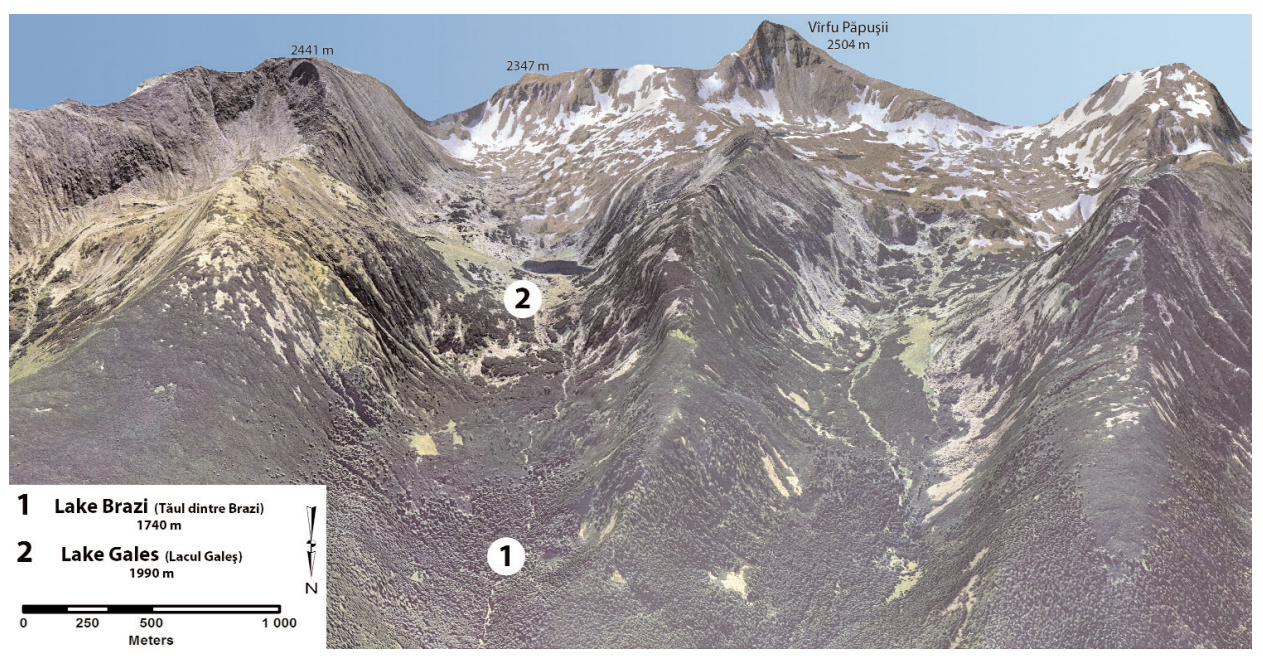

Fig. 2

Oblique aerial photograph of the region draped on a digital elevation model derived from corrected SRTM data. Viewed from the north

out. In order to compensate for this lag, an interdisciplinary project, PROLONGE (Providing long environmental records of Late Quaternary climatic oscillations in the Retezat Mountains), was launched in 2007, and sediment cores were obtained from four glacial lakes in the Retezat Mts (Figs 1 and 2). Here we report results from the study of the two northern slope lakes, Lake Brazi (Taul dintre Brazi) and Lake Gales (Lacul Galesu) (Fig. 2).

The aim of the PROLONGE project is to produce regional paleoclimatic and paleoecological records in a poorly-known high alpine mountain region using multiple paleoecological techniques: pollen, plant macrofossil, siliceous algae, Cladocera, chironomid, oxygen isotope and geochemical analyses. We focus on key sediment sections dated to two periods of rapid warming (GS-2/GI-1 and GS1/Holocene transitions at $\sim 14500$ and $\sim 11500 \mathrm{cal} \mathrm{yr} \mathrm{BP}$ ), develop chironomid and oxygen isotope based paleoclimate reconstructions, compare them with climate models and use them to evaluate the nature and speed of vegetational dynamics in response to environmental changes, such as variations in temperature, solar radiation and moisture availability. A second aim of the project is to reconstruct the chronology and structure of the Holocene tree line oscillations in the Retezat Mts.

The accuracy of the paleo-proxy records largely depends on exact dating of the sediment sequences (Walker 2005). As a first step, therefore, we describe the radiocarbon chronology of the two northern slope lake sediment sequences (TDB-1 and Gales-3), for which high-resolution biotic and abiotic proxy analyses have been carried out or are in progress (Buczkó et al. 2009; Magyari et al. 2009a; Buczkó et al., this issue). We also discuss the problems and merits of the age- 
depth models developed using a large set of radiocarbon dates. Subsequently the radiocarbon chronologies are used to infer the time by which these glacial lakes had become liberated from ice and sediment accumulation started. We also make climatic inferences using the sediment accumulation rate (SAR) and organic content records, and invoke the pollen record as an independent climatic proxy to confront the results.

\section{Study sites}

\section{Physical and natural setting}

The Retezat Mountains are one of the highest massifs in Romania, with the highest number of mountain peaks over $2,000 \mathrm{~m}$. The bedrock is predominantly granodiorite; however, strips of crystalline schist are intercalated between the two main intrusive blocks, the Retezat and the Buta Massifs. The highest peak is Peleaga $(2,509 \mathrm{~m})$. The number of peaks above 2,000 $\mathrm{m}$ a.s.l. is 55 , while the number of permanent glacial lakes is 58 (Jancsik 2001). The landscape has a typical alpine character since $25 \%$ of its total area is situated above the timberline $(\sim 1,800 \mathrm{~m}$ a.s.l.). The majority of glacial lakes are situated between $1,900-2,200 \mathrm{~m}$ a.s.l.; one exception is Lake Brazi, which is the lowest altitude glacial lake in the Retezat at 1,740 $\mathrm{m}$ a.s.l. (Fig. 1).

The Retezat is one of the wettest massifs in the Romanian Carpathians $(1,400$ $\mathrm{mm}$ yr-1 at 1,500-1,600 $\mathrm{m}$ a.s.l.), due to Mediterranean and oceanic influences (Jancsik 2001). The mean annual temperature is $6{ }^{\circ} \mathrm{C}$ in the foothill zone, but drops to $-2{ }^{\circ} \mathrm{C}$ at the highest peaks $(2,500 \mathrm{~m}$ a.s.l.). January is the coldest month with $-10{ }^{\circ} \mathrm{C}$ mean temperature at the peaks, while July is the warmest month, when mean temperatures range between 6 and $16{ }^{\circ} \mathrm{C}$ (Jancsik 2001). The $10{ }^{\circ} \mathrm{C}$ July isotherm runs parallel with the upper tree limit, at an altitude of $1,900 \mathrm{~m}$ on the southern flank, and around $1,800 \mathrm{~m}$ on the northern flank. Snowpack duration is 100 days at low altitudes and approximately 170 days at 2,000 m. Snow persists in some places even in the summer and sporadic permafrost occurs at some high elevation sites situated in favorable morphoclimatic conditions (Kern et al. 2004).

The flora of the Retezat Mts is rich in endemic species (Nyárádi 1958). Ninety of the recorded 1,190 plant species are endemic; these are mainly alpine meadow herbs (e.g. Hieracium borzae). Mixed oak forests are found between 550-700 (800) $\mathrm{m}$ a.s.l., followed by beech-fir forests between 700 and 1,200 $\mathrm{m}$ a.s.l., spruce forests between 1,200 and 1,850 $\mathrm{m}$ a.s.l. and dwarf pine thickets between 1,850 and 2,250 $\mathrm{m}$ a.s.l. Norway spruce (Picea abies) is often mixed with stone pine (Pinus cembra) and dwarf pine (Pinus mugo) in the upper limit of its range. Alpine meadows and pastures appear above 2,250 $\mathrm{m}$ with dwarf shrubs (Juniperus communis, Vaccinium myrtillus, V. vitis-idaea, Rhododendron myrtifolium).

Typical soil types are brown acid soil and feriiluvial brown, rendzina, brown eumezobazic soil, humicosilicatic soil, podsols and peat podsols. The podsol is 
the most frequent genetic type, not only in the alpine area, but also in the forests. The brown acid soils and brown eumezobazic soils are more frequent in the forests.

For the present research two lakes were selected from different altitudes on the northern flank: Lake Brazi (core TDB-1; 45 $23^{\prime} 47^{\prime \prime} \mathrm{N}, 2^{\circ} 54^{\prime} 06^{\prime \prime} \mathrm{E}$; $0.5 \mathrm{ha}$; 1,740 m a.s.l.; $1 \mathrm{~m}$ water depth) from the subalpine belt and Lake Gales (core Gales-3; $45^{\circ} 23^{\prime} 6^{\prime \prime} \mathrm{N}, 22^{\circ} 54^{\prime} 33^{\prime \prime} \mathrm{E}$; $3.68 \mathrm{ha}$; 2,040 $\mathrm{m}$ a.s.l.; $20 \mathrm{~m}$ water depth) from the alpine belt (Fig. 1). The lower lake is located in a mixed Norway spruce - stone pine forest, while the upper lake is ca. $150 \mathrm{~m}$ above the timberline in the dwarf pine zone (Fig. 1).

\section{Late Pleistocene Glacial Chronology in the northern Retezat Mts}

The northern part of the Retezat is characterized by high relief mountain summits (up to 2,509 $\mathrm{m}$ a.s.l.), well-developed U-shaped valleys covered by thick glacial deposits, and mountain ridges with glacially smoothed relief (former nunataks; Fig. 2) (Urdea 1993, 2000, 2001). Glacial morphology and the absolute time of the glacial advances have recently been studied by Urdea (2004) and Reuther et al. (2007) on the northern flank of the Retezat. According to their reconstruction, two major glacial advances took place during the last glacial period (Weichselian). During the Lolaia advance (M1; likely Early Weichselian) the pre-existing valley network on the southern slopes favored the coalescence of numerous small glaciers into an $18 \mathrm{~km}$-long glacial complex, whereas on the northern flank the glacier was only $7 \mathrm{~km}$ long. Glaciers descended to 1,060 and $1,035 \mathrm{~m}$ a.s.l. on the southern and northern slopes, respectively. The second major glacial advance, termed Capra-Judele (M2; glacier advance around 16.8 \pm $1.8 \mathrm{ka}$ BP; deglaciation started at $16.1 \pm 1.6 \mathrm{ka} \mathrm{BP}$ ) deposited terminal moraines on the northern slopes at 1,350 m a.s.l., $5.2 \mathrm{~km}$ north of the central crest (Reuther et al. 2007). Furthermore, a small Late Glacial re-advance (M3) was detected and dated between $13.6 \pm 1.5$ and $11.4 \pm 1.3 \mathrm{ka}$ BP on the northern slope (Reuther et al. 2007). Several authors argue that the last glacial maximum (LGM) was too dry in the Retezat Mts, the resulting aridity restricting the formation of valley glaciers (Posea 2002; Reuther et al. 2007). According to this glacial chronology, sediment accumulation in the glacial lakes likely started following the M2 advance, after $16.1 \pm 1.6 \mathrm{ka}$ BP.

\section{Genesis of the studied lake basins}

Lake Brazi is situated at the western marginal side of the Galesu glacial valley (Fig. 2). The area is covered by a spread boulder deposit probably linked to the well preserved frontal moraine visible on the opposite side of the valley. The irregular topographical setting of the lake basin is noteworthy. The lake is not situated at the valley bottom, but rather at an elevated level; thus, an erosional 
origin is unlikely. The symmetrical circular circumference, relatively small size and shallow depth suggest kettle-hole origin of the depression. Intensive regular or occasional debris supply could create debris mantle on the lateral section of the former glacier, of sufficient thickness to insulate the buried ice (Takeuchi et al. 2000) and prevent it from rapid melting (Schomacker 2008). As the glacier retreated, the buried ice was detached from the main ice body and became a dead ice lens that was preserved for a time under the debris mantle.

From a genetic viewpoint Lake Gales is a regular alpine lake. Its basin is a glacially-carved depression deepened in the cirque floor at the lower sector of the main corrie of the Galesu glacial valley (Fig. 2).

\section{Methods}

Coring and lithostratigraphic description

The 490-cm sediment core TDB-1 was taken in the central part of Lake Brazi with a modified Livingstone piston corer $7 \mathrm{~cm}$ in diameter, in August 2007. At the core location water depth was $110 \mathrm{~cm}$. Core segments of $1 \mathrm{~m}$ length were retrieved in plastic pipes, wrapped and transported to the laboratory where they were stored at $2{ }^{\circ} \mathrm{C}$ until further treatment. Coring stopped where glacial till was reached. Sediment lithology was recorded in the laboratory following the system of Troels-Smith (1955), immediately after cutting the plastic pipes lengthwise.

The 328-cm sediment core Gales-3 was taken in the central part of Lake Gales using a modified Kullenberg corer $7 \mathrm{~cm}$ in diameter (Emery and Broussard 1954). At the core location water depth was $19.5 \mathrm{~m}$. Using a 4-m long plastic pipe with a piston, Gales-3 was cored in one section; therefore, correlation problems between core sections are avoided. Sample storage and stratigraphic description of the profile was as described for TDB-1.

\section{Radiocarbon dating}

In order to restrict contamination by old carbon, special emphasis was laid on selecting terrestrial plant macrofossils for AMS 14C dating. Plant macrofossils were abundant in the Holocene part of both TDB-1 and Gales-3, and some plant macrofossils were also found in the Late Glacial section of TDB-1. The Late Glacial part of Gales-3 did not contain terrestrial plant remains. Therefore, we attempted to date Cladocera eggs (epipphia). In addition, to confirm that Cladocera-derived ${ }^{14} \mathrm{C}$ dates are not affected by residual old carbon, we dated plant macrofossils and Cladocera remains from the same sediment sample in Gales-3 at $179 \mathrm{~cm}$ (Table 1).

The material selected for dating was carefully cleaned of contamination and pre-treated with the AAA method (Mook and Streurman 1983) in order to remove humic acids and recently introduced $\mathrm{CO}_{2}$. Subsequently, air-dried samples were transferred to plastic containers and sent to the Poznan Radiocarbon Laboratory for dating. 
Table 1

Radiocarbon dates from Lake Brazi (TDB-1) and Lake Gales (Gales-3), Retezat Mts., Romania. AMS

${ }^{14} \mathrm{C}$ dates were obtained from the Poznan Radiocarbon Laboratory, Poland

\begin{tabular}{|c|c|c|c|c|c|c|}
\hline Core & $\begin{array}{l}\text { Laboratory } \\
\text { code }\end{array}$ & Dated material & $\begin{array}{l}\text { Depth } \\
(\mathrm{cm})\end{array}$ & $\begin{array}{l}{ }^{14} \mathrm{C} \text { age } \\
\text { years } \mathrm{BP}\end{array}$ & $\begin{array}{c}\text { Calibrated } \\
\text { range } \\
\text { years BP (2?) }\end{array}$ & Remarks \\
\hline TDB-1 & Poz-26103 & Picea abies needles & 119 & $725 \pm 30$ & $652-723$ & \multirow[t]{5}{*}{ suspect } \\
\hline TDB-1 & Poz-26104 & Pinus mugo cone scale & 160 & $1735 \pm 30$ & $1562-1712$ & \\
\hline TDB-1 & Poz-26106 & Pinus mugo cone & 238 & $3045 \pm 30$ & $3205-3356$ & \\
\hline TDB-1 & Poz-26107 & Pinus twig & 315 & $5040 \pm 40$ & $5708-5902$ & \\
\hline TDB-1 & Poz-26108 & Picea abies needles & 355 & $6320 \pm 40$ & $7163-7324$ & \\
\hline TDB-1 & Poz-26109 & Picea abies needles & 393 & $6130 \pm 40$ & $6926-7160$ & outlier \\
\hline TDB-1 & Poz-26110 & $\begin{array}{l}\text { Picea abies seed \& } \\
\text { needles }\end{array}$ & 450 & $8240 \pm 50$ & $9072-9326$ & \multirow{7}{*}{ suspect } \\
\hline TDB-1 & Poz-26111 & Picea abies needles & 505 & $8810 \pm 50$ & 9670-9966 & \\
\hline TDB-1 & Poz-31714 & Pinus mugo needles & 521 & $9150 \pm 50$ & $10223-10432$ & \\
\hline TDB-1 & Poz-26112 & Picea abies cone & 545 & $9610 \pm 50$ & $10764-11165$ & \\
\hline TDB-1 & Poz-31715 & Pinus mugo needles & 557 & $9980 \pm 100$ & $11216-11618$ & \\
\hline TDB-1 & Poz-31716 & charcoal & 569 & $10870 \pm 70$ & $12598-12925$ & \\
\hline TDB-1 & Poz-27305 & Pinus sp. needles (2) & 578 & $11590 \pm 60$ & $13287-13620$ & \\
\hline TDB-1 & Poz-26113 & $\begin{array}{l}\text { Picea abies cone } \\
\text { scales }\end{array}$ & 591 & $9690 \pm 50$ & $11067-11225$ & outlier \\
\hline Gales-3 & Poz-26114 & Pinus twig & 15 & $2075 \pm 30$ & $1985-2129$ & \multirow{7}{*}{$\begin{array}{c}<0.02 \mathrm{mg} \mathrm{C} \text {, } \\
\text { too small }\end{array}$} \\
\hline Gales-3 & Poz-26116 & Pinus mugo cone & 43 & $2500 \pm 35$ & 2458-2738 & \\
\hline Gales-3 & Poz-0 & Pinus twig & 102 & $>0 \mathrm{BP}$ & & \\
\hline Gales-3 & Poz-26117 & Pinus twig & 150 & $5380 \pm 40$ & $6172-6283$ & \\
\hline Gales-3 & Poz-27308 & Pinus needle & 179 & $8240 \pm 50$ & $9072-9326$ & \\
\hline Gales-3 & Poz-27307 & Cladocera & 179 & $8170 \pm 70$ & $8992-9318$ & \\
\hline Gales-3 & Poz-26118 & Cladocera & 213 & $10510 \pm 70$ & $12363-12605$ & \\
\hline Gales-3 & Poz-27309 & Cladocera & 261 & $10390 \pm 100$ & $11967-12576$ & \multirow{2}{*}{$\begin{array}{c}0.19 \mathrm{mg} \mathrm{C} \\
\text { small, } \\
0.5 \mathrm{mg} \mathrm{C}\end{array}$} \\
\hline Gales-3 & Poz-26132 & Cladocera & 281 & $7880 \pm 60$ & $8552-8812$ & \\
\hline Gales-3 & Poz-0 & Cladocera & 315 & $>0 \mathrm{BP}$ & & $\begin{array}{l}\text { too small, } \\
<0.02 \mathrm{mg} \mathrm{C}\end{array}$ \\
\hline Gales-3 & Poz-27310 & Cladocera & 317 & $>0 \mathrm{BP}$ & & $\begin{array}{l}\text { too small, } \\
0.02 \mathrm{mg} \mathrm{C}\end{array}$ \\
\hline
\end{tabular}

BCal calibration and psimpoll age model calculation

For the calibration of ${ }^{14} \mathrm{C}$ dates we used Bcal (Buck et al. 1999), an on-line Bayesian radiocarbon calibration tool (http://bcal.shef.ac.uk). BCal gives the posterior probability distributions on the calendar scale for all dated depths. These probability distributions are then exported as text files, which are then read as input to psimpoll (Bennett 2005). In psimpoll, point estimates of calendar ages are drawn repeatedly from the probability distributions of the dated levels, each time calculating an age model from the drawn point estimates. Six age models can be chosen in psimpoll (Bennett 2005); for this study loess smoothing (Cleveland and Devlin 1988) and linear interpolation were applied between the dated levels. Loess smoothing fits curves to noisy data by a multivariate smoothing procedure in a moving fashion that is analogous to how a moving average is computed for a time series. Linear interpolation involves connecting the date estimates to each other by lines of constant gradient, giving an overall model that can change at each date. Although it is known that this must be 
wrong, the method nevertheless provides an age-depth model that is hard to beat with more sophisticated methods (Bennett and Fuller 2002). In addition, a non-linear weighted regression function was also applied on the probability distributions of Late Glacial and Early Holocene radiocarbon dates from TDB-1.

Loss-on-ignition and biogenic silica analyses

Loss-on-ignition (LOI) analysis was used to determine the organic content of the sediment. It was carried out on $1 \mathrm{~cm}^{3}$ samples at $550{ }^{\circ} \mathrm{C}$ following the recommendations of Heiri et al. (2001). LOI was measured only in samples of TDB-1 taken at $1 \mathrm{~cm}$ (Late Glacial) and $4 \mathrm{~cm}$ (Holocene) intervals.

\section{Pollen analysis}

Samples of $1 \mathrm{~cm}^{3}$ (Holocene) and $2 \mathrm{~cm}^{3}$ (Late Glacial) wet sediment were prepared for pollen analysis in the laboratory using standard methods (Moore et al. 1992) but leaving the acetolysis step out. Pollen and spores were identified and counted under the microscope at $\times 400-1000$ magnification (see Magyari et al. (2009a, in prep.) for details.

\section{Results, paleoenvironmental and paleoclimatic inferences}

Radiocarbon dates from TDB-1 and Gales-3

Altogether 25 samples were sent out for radiocarbon dating to the Poznan Radiocarbon Laboratory in Poland. AMS ${ }^{14} \mathrm{C}$ dates were obtained in 22 cases; the rest of the samples contained too little carbon and were therefore unsuitable for dating. Table 1 presents the AMS ${ }^{14} \mathrm{C}$ age determinations, along with 2 ? ranges for calibrated ages, obtained using BCal (Buck et al. 1999; http:// bcal.sheffield.ac.uk) and the intcal09 calibration curve (Reimer et al. 2009), depths from which subsamples were taken and details of material dated.

Radiocarbon dates from the lower-lying lake, Lake Brazi, show a robust agedepth relationship: the dates generally increase with depth; only two outliers were detected at 393 and $591 \mathrm{~cm}$. These two AMS ${ }^{14} \mathrm{C}$ dates were rejected on the ground of the stratigraphic reversal. The Norway spruce (Picea abies) cone scale at $591 \mathrm{~cm}$ gave a much younger age than the sample above it (Table 1). This cone scale was probably split off from the spruce cone at $545 \mathrm{~cm}$ and drifted down during the coring process. The similarity of the radiocarbon ages of these two samples (9690 \pm 50 and $\left.9610 \pm 50{ }^{14} \mathrm{C} \mathrm{yr} \mathrm{BP}\right)$ and their taxonomic identity seem to support this inference. The second reversed age is at $393 \mathrm{~cm}$; this ${ }^{14} \mathrm{C}$ date is older than the date above it (at $355 \mathrm{~cm}$ ). In this case contamination was not detected in the sediment; therefore, the cause of this age reversal remains unknown. 
${ }^{14} \mathrm{C}$ age determinations from the Holocene part of the upper lake sediment, Lake Gales, are generally acceptable: radiocarbon ages increase with depth (Table 1). Furthermore, the plant macrofossil and Cladocera samples at $179 \mathrm{~cm}$ gave very similar ${ }^{14} \mathrm{C}$ ages suggesting that reservoir effect did not occur in the aquatic environment. Despite this generally good agreement between the plant macrofossil and Cladocera dates, Cladocera-based radiocarbon ages are inconsistent as we move to the Late Glacial organic-poor sediment, where plant macrofossils were absent. In this part of the core radiocarbon ages are stratigraphically reversed. As shown in Table 1, the carbon content of these Cladocera samples was very low (e.g. $0.19 \mathrm{mg} \mathrm{C}$ ); thus contamination by minute amounts of younger carbon can probably be blamed for the younger-thanexpected radiocarbon dates.

Our attempt to date the start of sediment accumulation in Lake Gales by ${ }^{14} \mathrm{C}$ has thus failed, as none of the Cladocera samples had enough carbon for dating below $300 \mathrm{~cm}$. Accordingly, the possibility to obtain information on the age of lake formation remains by comparison of the well-dated TDB-1 pollen record with the Gales-3 pollen record (see below).

Radiocarbon data from Lake Brazi suggest that sediment accumulation in this lake started earlier than $13,400 \mathrm{cal}$ year BP and was continuous throughout the Late Glacial and Holocene until present. The Gales-3 sequence, on the other hand, probably does not represent the last two millennia of the Holocene; a Pinus twig dated to ca. 2,060 cal yr BP at $15 \mathrm{~cm}$ suggests that coring either started well below the unconsolidated sediment surface and thus failed to sample the last two millennia, or the Pinus twig moved upward during the downhill transportation of the cores, when mixing of the top unconsolidated sediment layers was possible due to the difficult terrain.

\section{Age-depth modeling and sediment accumulation rates}

In order to estimate the start of sediment accumulation and infer past sediment accumulation rates in the lower-lying lake, Lake Brazi, age-depth modeling was performed using radiocarbon dates from TDB-1 and various curve-fitting methods in psimpoll (Bennett 2005). TDB-1 has a reliable and relatively large set of radiocarbon data making age-depth modeling feasible. Age-depth modeling was, however, not attempted in Gales-3 because of the insufficient number of reliable radiocarbon dates in this core.

Figures 3 and 4 display age-depth models from TDB-1. Depending on the linefitting method used, the start of sediment accumulation in TDB-1 was estimated at 15,124 -15,755 cal yr BP. In the Late Glacial part of the core (between ca. 15,755 and 11,550 cal yr BP) sediment accumulation rates (SAR) are generally low; depending on the curve-fitting method used, SAR range 74-104 years $\mathrm{cm}^{-1}$ between ca. 15,755 and 13,500 cal yr BP. This corresponds to the extrapolated and hence most ambiguous part of the age-depth curve; nonetheless the projected 
accumulation rates are in agreement with the expected unproductive environment. Sediment accumulation rates stay around 76 years $\mathrm{cm}^{-1}$ until $12,740 \mathrm{cal}$ yr BP if linear interpolation is used, but decrease gradually to 68 years $\mathrm{cm}^{-1}$ if loess-smoothing is used (Fig. 3). A major decrease in SAR is detected by the linear curve fitting method between 12,740 and 11,645 cal yr BP, when very low SAR values were inferred (91 years $\mathrm{cm}^{-1}$ ). It is notable that this time period broadly corresponds with the Younger Dryas reversal (GS-1; 12,800-11,500 cal yr $\mathrm{BP})$. When loess smoothing is used, this abrupt decrease in SAR is obscured,

(a) linear interpolation (12 dates)

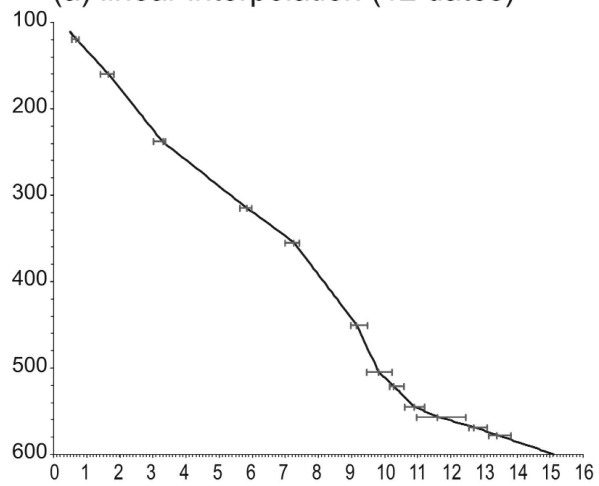

(c) linear interpolation (10 dates)
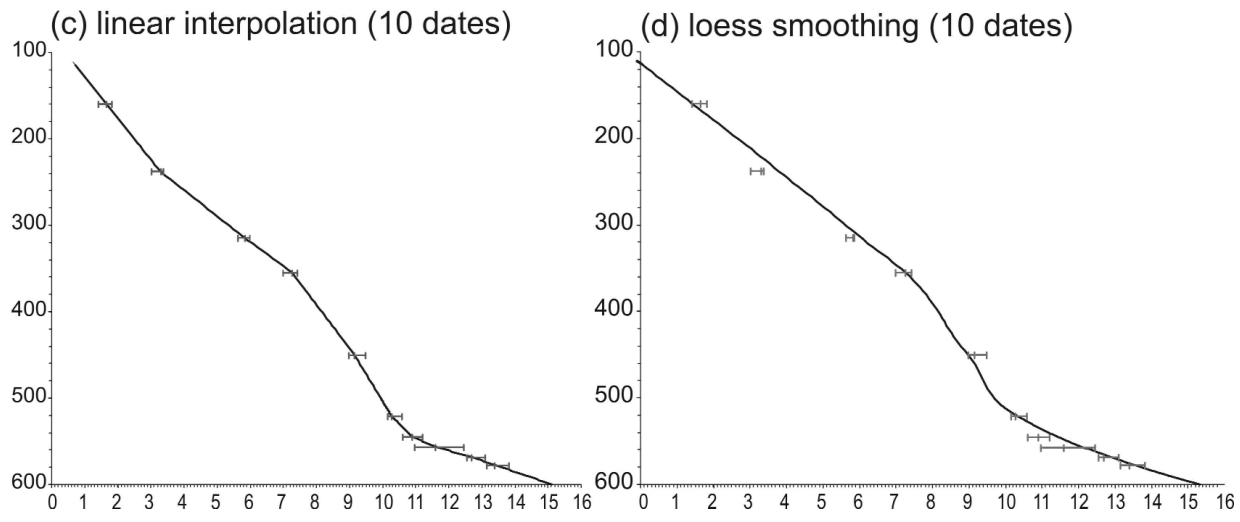

(b) loess smoothing (12 dates)

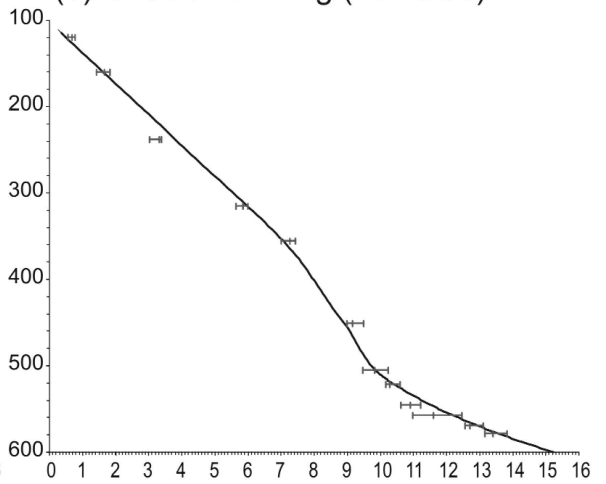

(d) loess smoothing (10 dates)

Fig. 3

Age models for the TDB-1 (Lake Brazi) site: (a) age-depth model based on $12{ }^{14} \mathrm{C}$ dates, calibration using $\mathrm{BCal}$ and age-model production using linear interpolation in psimpoll; thick gray horizontal lines indicate the posterior probability distribution of the radiocarbon dates and the middle vertical lines indicate the mode of posterior probability distribution; solid line indicates the psimpoll age model; (b) age-depth model based on $12{ }^{14} \mathrm{C}$ dates, calibration using $\mathrm{BCal}$ and age-model production using loess smoothing in psimpoll, features as per (a); (c) age-depth model based on $10{ }^{14} \mathrm{C}$ dates, calibration using $\mathrm{BCal}$ and age-model production using linear interpolation in psimpoll, features as per (a); (d) age-depth model based on $10{ }^{14} \mathrm{C}$ dates, calibration using $\mathrm{BCal}$ and age-model production using loess smoothing in psimpoll, features as per (a)

Central European Geology 52, 2009 
because the fitted curve runs outside the posterior probability distributions (see Fig. 3). In general the BCal-loess interpolation model performed badly in the Late Glacial section of the core; the fitted curve runs outside of two calibrated age ranges, suggesting a biased model. The BCal-linear model, on the other hand, includes several abrupt shifts in SAR by nature, making it also unrealistic. For these reasons we tried a third method, weighted non-linear polynomial regression that we applied exclusively on the Late Glacial and Early Holocene sediment sections (Fig. 4). The advantage of this method over BCal-psimpoll models is that it takes into account the probability values of the calibrated ages within the posterior probability range (i.e. gives them a weight). The regression

Fig. 4

Non-linear weighted polynomial regression for modeling age-depth relationship in the Late Glacial and Early Holocene part of TDB-1 (Lake Brazi, South Carpathians). The 3D image displays the regression line and the posterior probability distributions of the ${ }^{14} \mathrm{C}$ dates

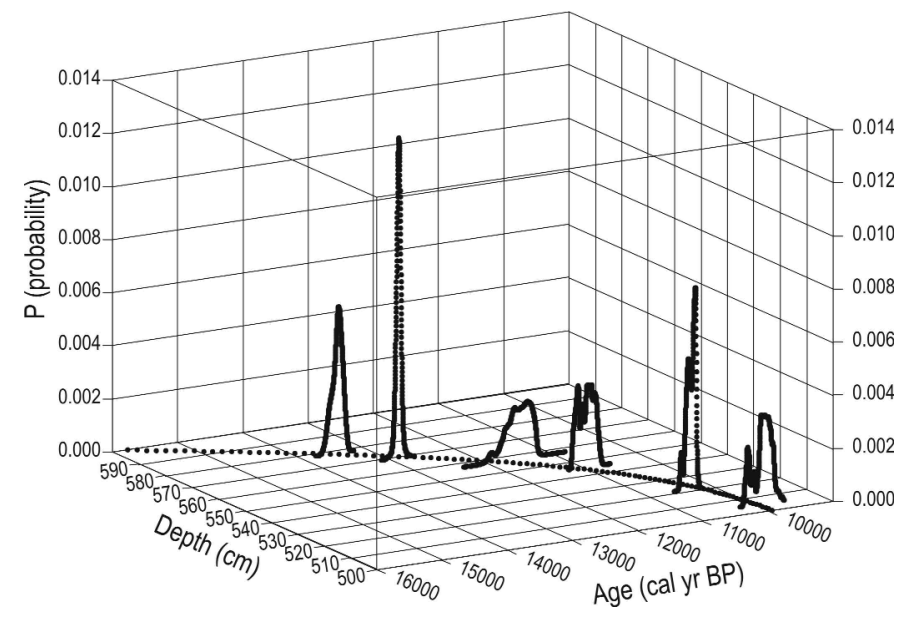

line between the dated horizons was drawn so as to minimize the sum of least squares. This age-depth curve (Fig. 4) runs through calibrated ages with high probability values and its extrapolated end estimates the start of sediment accumulation at $15,755 \mathrm{cal}$ yr BP (oldest of all estimates). The curve suggests a near-linear age-depth relationship until ca. 11,800 cal yr BP, followed by rapid increase in SAR in the Early Holocene. Given that pollen zone boundaries showed the best fit with the Late Glacial event stratigraphy using this age model (Fig. 5, see details below), plus that it is the one which takes into account the posterior probability values and does not run outside the $95 \%$ confidence interval, we chose this age model when plotting biotic and abiotic paleoenvironmental proxies from the Late Glacial and Early Holocene part of TDB-1 (Fig. 5; data in Appendix 1).

In the Holocene part of core TDB- 1 far fewer ${ }^{14} \mathrm{C}$ dates are available and accordingly the BCal-loess and BCal-linear interpolation models are simpler: they both indicate a gross increase in SAR in the Early Holocene, at ca. 10,800 cal yr BP (values between 16-20 $\mathrm{yr} \mathrm{cm}^{-1}$ ), followed by decrease at ca. $7140 \mathrm{cal} \mathrm{yr} \mathrm{BP}$ (values around 33-35 years $\mathrm{cm}^{-1}$ ) and a second period of increased SAR between 3,210 and 1,520 cal yr BP (Figs 3a and 3c). In comparison with the Late Glacial, 


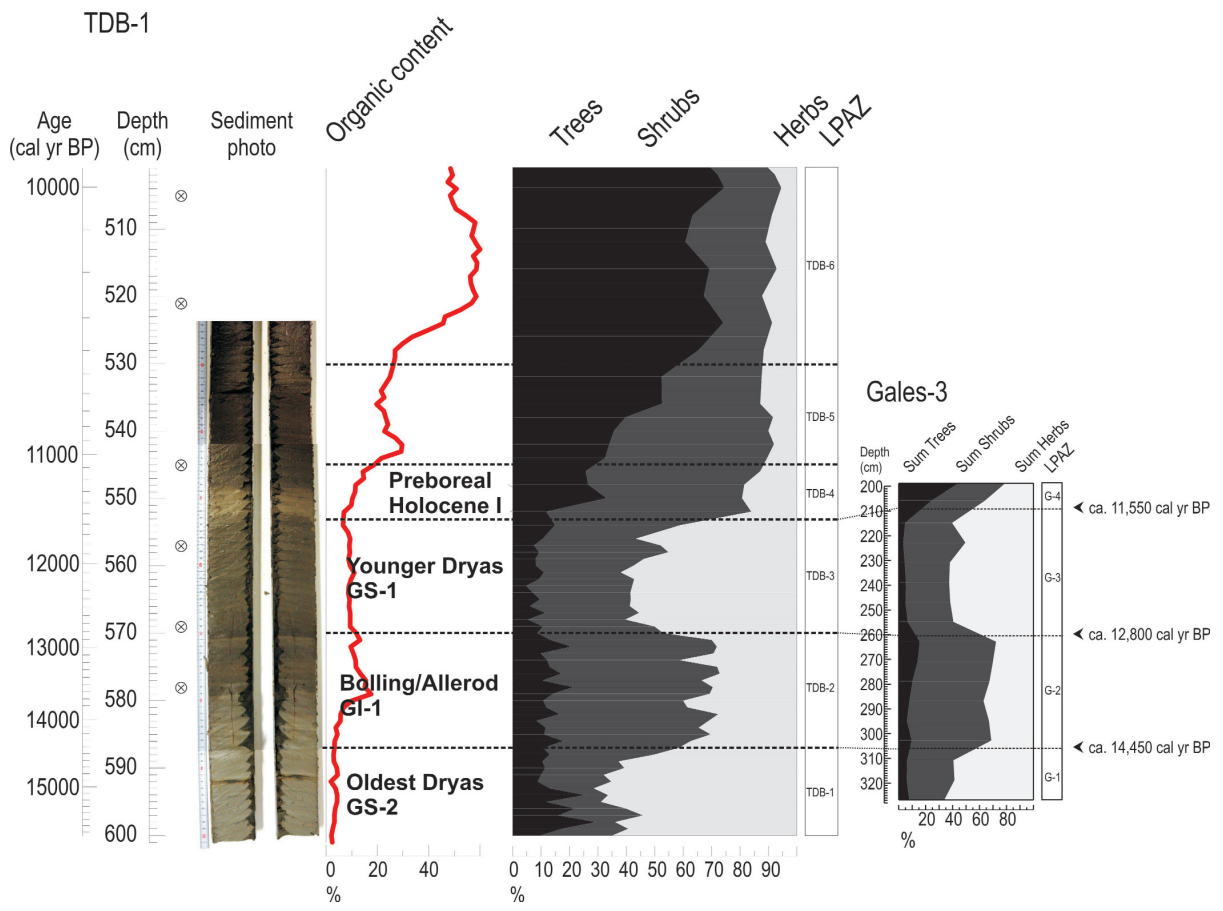

Fig. 5

Sediment photo, lithostratigraphy, organic matter content as percentage loss-on-ignition at $550{ }^{\circ} \mathrm{C}$ (organic content, \% DW) and summary pollen diagrams of the Late Glacial and Early Holocene layers from TDB-1 (Lake Brazi) and correlation of pollen zone boundaries of TDB-1 with Gales-3 (Lake Gales). LPAZ: local pollen assemblage zones

sediment accumulated much faster during the Holocene, and if BCal loesssmoothing is applied the age-depth relationship is linear after 7,270 cal yr BP (Figs $3 \mathrm{~b}$ and $3 \mathrm{~d}$ ), implying steady sediment accumulation rates. The linear interpolation models also suggest only small departures from a linear age-depth relationship. The models were run in two different ways for the Holocene; Figures $3 \mathrm{a}$ and $3 \mathrm{~b}$ display results including all non-outlier dates, while Figures $3 \mathrm{c}$ and $3 \mathrm{~d}$ display age models that do not use two suspicious radiocarbon dates from 505 and $119 \mathrm{~cm}$. The former is probably too young, though its calibrated age range is wide (Fig. 3a; Table 1) and thus both BCal-linear and BCal-loess agedepth curves traverse it. The latter is probably too old: the mode of its calibrated age range is $673 \mathrm{cal}$ yr BP despite its position being near the sediment surface ( 9 $\mathrm{cm}$ below). Since the sediment surface was clearly visible during the coring process and securely sampled, the most likely explanation of this discrepancy is sediment mixing during transportation, similarly to Gales-3.

Using the age-depth models discussed above we developed a consensus timescale for TDB-1 that for the Late Glacial uses the weighted non-linear polynomial regression model (Fig. 4), and for the Holocene the BCal-linear 
Radiocarbon chronology of glacial lake sediments in the Retezat Mts 237

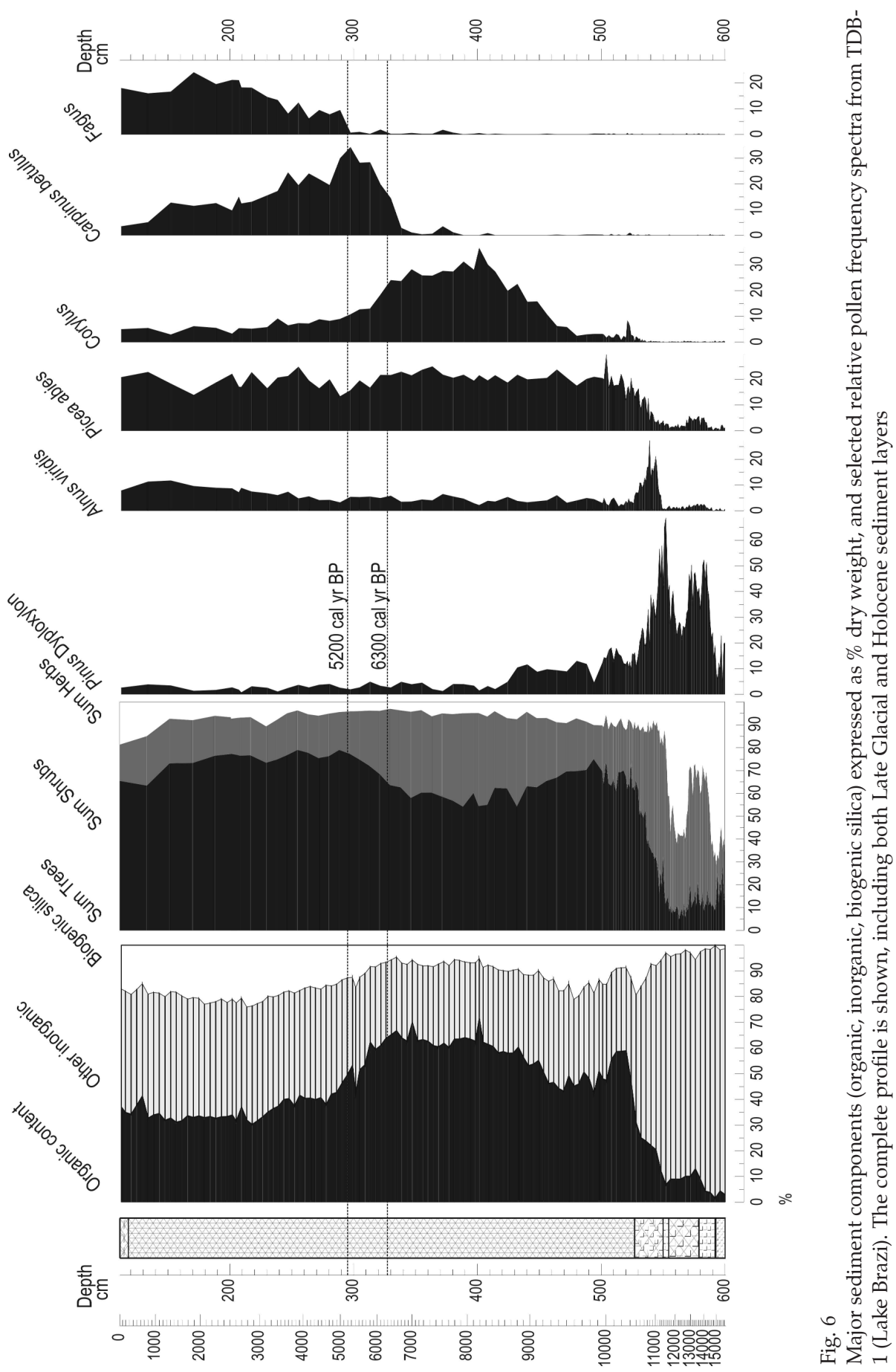

Central European Geology 52, 2009 
interpolation model (Fig. 3c). The consensus timescale and age-depth model is presented in Appendix 1 and is used in Fig. 6.

\section{Relative dating of Gales-3 by pollen zone boundaries}

As discussed above, reliable radiocarbon dates were not obtained from the Late Glacial part of Gales-3. We looked for a different method to date the Late Glacial part of this record and found that similar pollen stratigraphic changes in Gales-3 and TDB-1 can be used to match the two records and transfer pollen zone boundary ages from the well-dated TDB-1 record to Gales-3. These were then used to infer the start of sediment accumulation in Gales-3. Figure 5 displays summary pollen diagrams from the Late Glacial and Early Holocene parts of both records with pollen zone boundaries and their correlation. The detailed description and interpretation of these profiles is published elsewhere (Magyari et al. 2009a, in prep). During the Late Glacial, characteristic changes in the relative frequencies of total arboreal pollen are seen in both records, namely at ca. 14,450 cal yr BP, a massive increase in tree and shrub pollen frequencies is seen in TDB1 that is also detectable in Gales-3 at $306 \mathrm{~cm}$, and at ca. 12,800 cal yr BP, when arboreal pollen frequencies decrease markedly in TDB-1 and a similar change is also present in Gales-3 at $260 \mathrm{~cm}$ (Fig. 5). These high-amplitude, changes are characteristic for the Late Glacial and be correlated with the Bølling/Allerød interstadial (GI-1) and the Younger Dryas stadial (GS-1; see Fig. 5). If we apply these pollen zone boundary dates to Gales-3, then the start of sediment accumulation is inferred to be $>14,500$ cal yr BP, most likely between $15,000-16,000$ cal yr BP.

\section{Changes in sediment stratigraphy, organic content and biogenic silica}

The 328-cm sediment sequence from Lake Gales (Gales-3) was classified into ten lithostratigraphic units (Table 2). The lowest part of the sediment profile (328-269 cm, units 1-2) exhibits light-colored silt and clay dominated sediments with low organic matter content (note that loss-on-ignition results are not yet available from Gales-3). Although the pollen record clearly indicates the onset of the Bølling/Allerød interstadial from $306 \mathrm{~cm}$ by increasing tree and shrub pollen suggesting regional forestation, it seems that locally productivity did not increase significantly within and around the lake. The change to greenish-grey silty clay at $269 \mathrm{~cm}$ slightly predates the Younger Dryas (YD) cooling $(260 \mathrm{~cm})$, while the pollen record suggests de-forestation and expansion of tundra and cold continental steppe vegetation (Magyari et al. 2009a; Fig. 5). The color change indicates slightly increasing productivity in and around the lake implying that the YD cooling is not expressed in the sediment stratigraphy. The change to midbrown/mid-grey silty clay at $206 \mathrm{~cm}$ correlates well with the onset of the Holocene warming placed at $209 \mathrm{~cm}$ in the pollen diagram (Fig. 5). The sediment 
becomes gradually more organic-rich, suggesting gradual increase in ecosystem productivity that is in line with the regional climatic trend. Following this transitional layer, the Holocene layers are organic rich gyttja sediments (finegrained, nutrient-rich organic mud) with occasional intercalation of silty clay layers likely representing episodes of enhanced lakeshore erosion and/or fluvial activity.

The 490-cm sediment sequence from Lake Brazi (TDB-1) was classified into eight lithostratigraphic units (Table 2, Figs 5 and 6), and from this core loss-onignition and biogenic silica measurements are also available (Figs 5 and 6). The

Table 2

Sediment stratigraphy of TDB-1 (Lake Brazi) and Gales-3 (Lake Gales), Retezat Mountains, South Carpathians, Romania

\begin{tabular}{|c|c|c|c|}
\hline Unit & Depth (cm) & $\begin{array}{l}\text { Troels-Smith } \\
\text { symbols }\end{array}$ & Description \\
\hline & TDB-1 & & \\
\hline & $0-110$ & & water \\
\hline 8 & $110-118$ & Ld2Tb1Tl1Th1As+ & dark brown detritus gyttja; frequent wood remains \\
\hline 7 & $118-527$ & Ld3Th1Tb+TI+As+ & $\begin{array}{l}\text { mid brown - dark brown fine gyttja rich in plant } \\
\text { macrofossils, charcoal and wood remains; gradual color } \\
\text { change over the core segment from mid brown to dark } \\
\text { brown; water content decreases below } 345 \mathrm{~cm} \text {; 236- } \\
239 \mathrm{~cm} \text { : Pinus mugo cone }\end{array}$ \\
\hline 6 & $527-550$ & As2Ld1Th+Tl+Ag1 & mid grey - mid brown silty gyttja \\
\hline 5 & $550-554.5$ & As2Ag2Ld+Th+Tl+ & $\begin{array}{l}\text { light grey - light brown silty clay poor in detritus and } \\
\text { macrofossils }\end{array}$ \\
\hline 4 & $554.5-579$ & Ld2As1Ag1Th+TI+ & $\begin{array}{l}\text { mid grey - mid brown clay gyttja with increased organic } \\
\text { content; darker and lighter bands alternate }\end{array}$ \\
\hline 3 & $579-592$ & As2Ag2Ld+Th+TI+ & $\begin{array}{l}\text { mid grey silty clay with faint lamination (alternation of } \\
\text { light and darker layers) }\end{array}$ \\
\hline 2 & $592-592.5$ & Gs3Sh1 & blackish grey sand lens \\
\hline \multirow[t]{2}{*}{1} & $592.5-600$ & As4Ag+Ld+Th+ & mid grey - light brown silty clay \\
\hline & GALES-3 & & \\
\hline 10 & $0-75$ & Ld3Th1TI+Tb+ & $\begin{array}{l}\text { dark brown gyttja rich in plant macrofossils and } \\
\text { Cladocera remains }\end{array}$ \\
\hline 9 & $75-137$ & Ld4Th+Tb+Tl+ & $\begin{array}{l}\text { dark brown fine gyttja; lighter color between 101.5-104 } \\
\mathrm{cm} \text { and at } 114 \text { and } 123 \mathrm{~cm}\end{array}$ \\
\hline 8 & $137-139.5$ & Ld3As1Th+Tb+ & $\begin{array}{l}\text { mid grey - mid brown clay/silt-rich gyttja, sharp lower } \\
\text { boundary }\end{array}$ \\
\hline 7 & $139.5-160$ & Ld4Th+Tb+Tl+ & dark brown fine gyttja \\
\hline 6 & $160-164$ & Ld3As1Ga+Th+Tb+ & $\begin{array}{l}\text { mid grey - mid brown clay and silt rich gyttja; lower } \\
\text { boundary shows yellowish color with fine sand }\end{array}$ \\
\hline 5 & 164-199 & Ld4Th+Tb+Tl+ & dark brown fine gyttja \\
\hline 4 & 199-206 & Ld2As2Tg+ & $\begin{array}{l}\text { mid brown - mid grey transitional layer, gradual change } \\
\text { in color (getting lighter downward with decreasing } \\
\text { organic content); Cladocera epipphia are abundant }\end{array}$ \\
\hline 3 & $206-269$ & As3Ld1Ag+ & $\begin{array}{l}\text { greenish grey silty clay; at } 208 \mathrm{~cm} \text { darker color; below } \\
210 \mathrm{~cm} \text { coarse sand is present }\end{array}$ \\
\hline 2 & 269-271 & As3Ga1Ld+Th+ & light grey sandy silty clay \\
\hline 1 & $271-328$ & As3Ga1Ld+ & $\begin{array}{l}\text { yellowish grey compact silty clay, occasional coarse } \\
\text { sand }\end{array}$ \\
\hline
\end{tabular}


bottom 3 sediment units (units 1-3) are characterized by light color, silt and clay dominance and sand intercalation (unit 2). LOI measurements furthermore signal very low organic content in these sediment units, $2.1-4.4 \%$, that gradually increase to $10 \%$ toward the top samples of unit $3(579 \mathrm{~cm}=\mathrm{ca} .13,630 \mathrm{cal} \mathrm{yr} \mathrm{BP})$. Low biogenic silica content in these units supports in-lake productivity minimum inferred from low organic content, while gradually increasing LOI and biogenic silica values above $583 \mathrm{~cm}(14,000 \mathrm{cal}$ yr BP $)$, within the Bølling/Allerød interstadial (GI-1), suggest gradually increasing in-lake and lakeshore productivity. This is, however, considerably delayed (by 450 years) when compared with the pollen-inferred regional coniferous woodland and dwarf pine (Pinus mugo) scrubland expansion (Fig. 5) that commenced in the mountain area around 14,450 cal yr BP (Magyari et al. 2009a, in prep). The next sediment unit encompasses the second part of the Bølling/Allerød interstadial (GI-1) and the entire Younger Dryas stadial (GS-1) and despite the pollen-inferred cooling and de-forestation in GS-1 (broadly corresponds to local pollen assemblage zone 3 (TDB-3): 12,800-11,550 cal yr BP; see Fig. 5) the sediment color is darker in this unit and the average organic content is higher $(11 \%)$ than in units $1-3$, with peak organic content between 576 and $579 \mathrm{~cm}$ (13,350-13,630 cal yr BP; Fig. 5). This suggests only moderate productivity decrease during the Younger Dryas in and around Lake Brazi, similarly to Lake Gales. Biogenic silica content shows a similar pattern to LOI; only a moderate decrease is seen and this predates the Younger Dryas (Fig. 6). In comparison with the Holocene, however, biogenic silica content is very low $(2-5 \%)$, suggesting generally low diatom productivity during the Late Glacial (Fig. 6). Sediment unit 5 is a thin $(4.5 \mathrm{~cm})$ light grey silty clay layer with decreased organic content (7\%; Fig. 5). Our radiocarbon chronology places the start of its accumulation around 11,650 cal yr BP, i.e. very near to the $\mathrm{YD} / \mathrm{Holocene}$ boundary. Although the pollen spectra of this unit clearly indicate coniferous woodland expansion regionally, the sediment has low organic and biogenic silica contents (Figs 5 and 6). This may reflect accelerated erosion caused by meltwater input, as the rapid temperature increase at the onset of the Holocene likely triggered rapid melting of the high-altitude glaciers (Reuther et al. 2007). Unit 6 is a transitional silty gyttja layer rich in plant macrofossils with gradually increasing organic content (Table 2; Fig. 5). True gyttja sediments accumulated from ca. 10,370 cal yr BP in units 7 and 8 (Table 2, Figs 5 and 6), suggesting high in-lake and lakeshore productivity. Organic content increased rapidly to $65 \%$ and retained high values until ca. $6300 \mathrm{cal}$ yr BP $(327 \mathrm{~cm})$. Only a small reversal to $45-50 \%$ is seen between 455 and $508 \mathrm{~cm}(10,060-9,250 \mathrm{cal} \mathrm{yr} \mathrm{BP})$. It is notable that biogenic silica increase in this interval and other inorganic components remains unchanged, suggesting increased siliceous algal productivity during this period. Two alternative interpretations are suggested for the increased siliceous algal productivity: (1) siliceous algae were probably favored over other algal groups for climatic reasons (in alpine oligotrophic lakes the decreasing duration of ice cover, elongation of the spring season and moderately warm summers result in the competitive vigor of diatoms over other algae; Lotter and Bigler 2000), or (2) the 
size of the water body increased and thus provided habitat for a larger siliceous algae population (Lotter et al. 2001). The gradual organic content decrease after 6,300 cal yr BP (centered around 5,200 cal yr BP; see Fig. 6) is also accompanied by increasing biogenic silica content and only a minor increase in other inorganic sediment components (Fig. 6). Note that this change is synchronous with a regional vegetation shift, namely the expansion of Carpinus betulus and later Fagus sylvatica in places formerly covered by mixed deciduous (Corylus, Quercus, Fraxinus, Tilia, Ulmus) forests (Fig. 7). Increasing biogenic silica content can be interpreted in the same way as between $455-508 \mathrm{~cm}$, and irrespective of which interpretation is accepted, these changes in the various proxies suggest a major ecosystem shift, most likely governed by macroclimate change around and after $6300 \mathrm{cal}$ yr BP. Cooling summer temperatures and/or increasing available moisture are inferred. Following the gradual decrease in organic content and increase in biogenic silica, the second part of the Holocene, after ca. $4500 \mathrm{cal}$ yr BP, is characterized by steady organic content values of around $35-40 \%$ (Fig. 6).

\section{Discussion}

\section{Glacial lake formation times in the northern Retezat}

The age-depth models developed for TDB-1 suggest that sediment accumulation in the glacial basin of Lake Brazi and Lake Gales started between about 15,124 and $15,755 \mathrm{cal}$ yr BP. In the absence of datable material, sediment bottom ages were inferred by extrapolation of the age-depth curves (Figs 3 and 4) and suggest that these two mountain sites (Lake Brazi at $1740 \mathrm{~m}$ a.s.l. and Lake Gales at $1990 \mathrm{~m}$ a.s.l.) were ice-free before the beginning of the Bølling period (GI-1). Deglaciation times inferred by Reuther et al. (2007) are in good agreement with our findings; they suggest the start of ice retreat and melting at around 16.1 $\pm 1.6 \mathrm{ka}$ BP in the Pietrele Valley (Fig. 2). This means that melting of the hypothesized buried ice lens at the site of Lake Brazi could have been delayed only by a few hundred years, owing to the insulating effect of the debris mantle. Our radiocarbon chronology, furthermore, shows very similar timing of lake formation with glacial lakes situated at similar latitudes and altitudes in the Southern Alps; e.g. sediment profiles from Totenmoss, Suossa, Passo del Tonale, Majola Riegel (these sites are at $46^{\circ}$ northern latitude) extend back to > 15,000 cal yr BP (Zoller and Kleiber 1971; Gehrig 1997; Heiss et al. 2005; Ilyashuk et al. 2009).

The M3 glacier re-advance in the northern Retezat (advance at 13.6 $\pm 1.5 \mathrm{ka} B \mathrm{BP}$; retreat at $11.4 \pm 1.3 \mathrm{ka} \mathrm{BP}$ ) that was confined to the upper cirque region (Reuther et al. 2007) can only be detected indirectly in Gales-3 and TDB-1. In TDB-1, organic content decreases after 13,600 cal yr BP suggesting decreasing in-lake and lakeshore productivity. This might be due to the cooling effect of the growing glaciers. Furthermore, the Early Holocene organic-poor sediment unit in TDB-1 (unit 5; Table 2) might have a connection with the accelerated meltwater pulses and erosion events at the time of the Early Holocene deglaciation. 
Late Glacial and Holocene climatic inferences and their regional comparison

We demonstrated above that local ecosystem productivity showed delayed response to Late Glacial and Early Holocene climate changes (recorded by $\delta^{18} \mathrm{O}$ in Greenland ice cores; Björck et al. 1998) in the subalpine and alpine zones of the Retezat. However, regional vegetation response was without time lag and indicated forestation and warming at 14,450 and 11,550 cal yr BP, and cooling at ca. $12,800 \mathrm{cal}$ yr BP. Thus regional vegetation and local ecosystem changes are offset in the northern Retezat Mountains. The most likely cause of the delayed response at high altitude in the Retezat is remnant ice that likely had a cooling effect, thus delaying local forest and soil development. During the Late Glacial the lake ecosystem was probably strongly affected by input of snowmelt water that resulted in a cold aquatic environment. This factor can be a possible interpretation for the delayed productivity increases in the lakes, both at the GS-2/GI1 and GS-1/Holocene transitions. Similar findings by Ilyashuk et al. (2009) in the Swiss Alps support this interpretation. Further support comes from geomorphological evidence, according to which stone glaciers existed during the M3 glacial advance in the northwestern part of the Gales firn basin (between 13.6 \pm 1.5 and $11.4 \pm 1.3 \mathrm{ka}$ BP) (Urdea 2004; Nagy, pers. com.). The ice core of these stone glaciers must have supplied cold water $\left(0.4-0.5^{\circ} \mathrm{C}\right)$ to Lake Gales during and probably well after the deglaciation, as similar stone glaciers still persist in the nearby Pietrele Valley (west of Lake Gales; Fig. 2) and also above Lake Lia on the southern flank of the Retezat (Nagy, pers. comm.).

In the upper lake (Lake Gales) organic sediment accumulation only began in the Early Holocene, at ca. 11,700 cal yr BP (Table 2). Again, similar results from deep lakes in the Swiss Alps suggest that the proximity of the remnant highaltitude glaciers to the alpine lakes further hampered aquatic productivity increase (Gobet et al. 2003).

Sediment stratigraphies and LOI measurements from TDB-1 suggested that inlake and lakeshore productivity did not decrease considerably during the YD reversal in Lake Brazi. Sediment accumulation rates, on the other hand, decreased considerably during the YD (12,800-11,550 cal yr BP; Appendix 1) suggesting that the net influx of organic and inorganic matter decreased, probably in response to longer ice cover. Overall, the moderate decrease in productivity can probably be explained by the position of the lake relative to the YD tree line. As evidenced by the pollen and macrofossil records (Magyari et al. 2009a; in prep., the catchment of the lake was situated below the tree line during the $Y \mathrm{D}$, and this may have mitigated local productivity response to the cooling. Nonetheless, the pollen records clearly indicate regional deforestation and expansion of steppe tundra vegetation at high altitudes in this period (Fig. 5).

In the Southern Alps, Late Glacial, and within it, some Younger Dryas sediments have high organic content. In the Palughetto basin, for example, a change from gyttja to peat coincides with the YD reversal (Vescovi et al. 2007) and 
suggests decreasing moisture availability during the $\mathrm{YD}$, but no drastic productivity decrease, similarly to Lake Brazi.

In the Romanian part of the Carpathians detailed Late Glacial sediment stratigraphies and LOI records are only available from lake sediment profiles in the Gutaiului Mountain (730 and 790 m a.s.l.; Feurdean and Bennike 2004; Wohlfarth et al. 2001; Fig. 1). Similarly to TDB-1 and Gales-3, lithostratigraphic changes in these sediment profiles show weak correlation with the Late Glacial event stratigraphy (Björck et al. 1998), though the pollen and macrofossil records clearly indicate warming and cooling episodes in line with the Late Glacial oxygen isotope phases (Feurdean and Bennike 2004). Organic content increased gradually during the Late Glacial in these sequences, similarly to TDB-1.

In the Retezat Mountains, the only site available for comparison is Taul Zanoguti (1840 m a.s.l.; Farcas et al. 1999; Feurdean et al. 2007). Although Pop and his colleagues studied several peat bogs in the Retezat for pollen (e.g. Lupsa 1968; Pop et al. 1971), other radiocarbon-dated Late Glacial profiles are not available. The lakeshore sediment sequence of Taul Zanoguti shows very slow sediment accumulation during the Late Glacial (Feurdean et al. 2007). It seems that $20 \mathrm{~cm}$ sediment represents nearly 4,500 years, between 14,800 and 11,500 cal yr BP, and displays very similar pollen stratigraphy to TDB-1 and Gales-3 with a marked Artemisia increase during the YD reversal. Very slow sediment accumulation rates during the Late Glacial can probably be connected to low in-lake productivity, but may also reflect the lakeshore position of the core; sediment probably drifted off towards the center in the lake phase. Nonetheless the radiocarbon chronology suggests that sediment accumulation in the lakeshore area of Taul Zanogutii started later than in TDB-1 and Gales-3, around 14,800 cal yr BP.

In the Holocene part of TDB-1, LOI and biogenic silica measurements suggested one major shift that started around 6,300 cal yr BP and culminated around 5,200 cal yr BP (Fig. 6). Physical proxies suggested summer cooling, shorter duration of the winter ice-cover season and/or increasing size of the water body, possibly in response to increasing available moisture. Lake level reconstructions from the Carpathian Mountains are scarce, but a crater lake in the Eastern Carpathians, Lake St Ana (Magyari et al. 2006, 2009b; Fig. 1), showed increasing lake levels nearly the same time, from ca. 5,350 cal yr BP. Further support for the regional extent of this climatic signal comes from Romanian stalagmites, where d 180 curves indicate the termination of the Early-Mid Holocene warming around 5,200 cal yr BP. After this date, stable and gradually declining isotope values were found punctuated by short-term increases and interpreted as a reflecting gradual decrease in annual temperatures with shortterm reversals to warm periods (Constantin et al. 2007). Furthermore, our inferred mid-Holocene summer cooling and winter warming show good agreement with the northern hemisphere summer and winter insolation curves that display higher than present summer insolation between 11,000-5000 cal yr BP followed by decline, and an opposite trend for winter insolation (Huybers 
2006; Wanner et al. 2008). Magny and Haas (2004) summarized correlative events in various regions at 5,600-5,200 cal yr BP and pointed out that a mid-Holocene climatic reversal is observable in both hemispheres. Prevailing climate cooling at that time resulted in glacier advance, decline in polar and mountain tree limits and increasing permafrost, among others.

\section{Conclusions}

We demonstrated in this study that local ecosystem productivity showed delayed response to Late Glacial and Early Holocene climatic changes in the subalpine and alpine zones of the Retezat Mountains, most likely attributable to the cooling effect of remnant glaciers and meltwater input. However, we also demonstrated that regional vegetation response was without time lag and indicated forestation and warming at 14,450 and 11,550 cal yr BP, and cooling at ca. 12,800 cal yr BP. In the Holocene, one major shift was detected, starting around $6,300 \mathrm{cal} \mathrm{yr} \mathrm{BP}$ and culminating around 5,200 cal yr BP. The various proxies suggested summer cooling, shorter duration of the winter ice-cover season and increasing size of the water body, most likely in response to increasing available moisture at the time of the mid-Holocene climatic reversal.

\section{Acknowledgements}

We are grateful to Judit Padisák and Balázs Nagy for improvements of the manuscript. This study was supported by the European Union Marie Curie Reintegration Grant (MERG-CT-041088) and the Hungarian Scientific Fund (OTKA PD73234). This is MTA-MTM contribution No. 119 
Appendix

Sediment depths, calibrated BP ages and sediment accumulation rates (SAR) from TDB-1 (Lake Brazi) on the basis of the consensus timescale that for the Late Glacial and Early Holocene use the nonlinear polynomial regression model (Fig. 6), while for the rest of the Holocene the linear interpolation model (Fig. 4c) is employed. See text for details

\begin{tabular}{|c|c|c|}
\hline $\begin{array}{c}\text { Depth } \\
\text { (cm) }\end{array}$ & $\begin{array}{c}\text { Age } \\
\text { (cal yr BP) }\end{array}$ & $\begin{array}{c}\text { SAR } \\
\left(\mathrm{yr} \mathrm{cm}^{-1}\right)\end{array}$ \\
\hline 600 & 15755.35 & 104.739 \\
\hline 599 & 15650.61 & 104.74 \\
\hline 598 & 15545.97 & 104.64 \\
\hline 597 & 15441.47 & 104.50 \\
\hline 596 & 15337.15 & 104.31 \\
\hline 595 & 15233.08 & 104.08 \\
\hline 594 & 15129.28 & 103.80 \\
\hline 593 & 15025.8 & 103.48 \\
\hline 592 & 14922.69 & 103.11 \\
\hline 591 & 14819.99 & 102.70 \\
\hline 590 & 14717.75 & 102.25 \\
\hline 589 & 14615.99 & 101.76 \\
\hline 588 & 14514.76 & 101.23 \\
\hline 587 & 14414.1 & 100.66 \\
\hline 586 & 14314.05 & 100.05 \\
\hline 585 & 14214.64 & 99.41 \\
\hline 584 & 14115.91 & 98.73 \\
\hline 583 & 14017.89 & 98.02 \\
\hline 582 & 13920.63 & 97.27 \\
\hline 581 & 13824.14 & 96.48 \\
\hline 580 & 13728.47 & 95.67 \\
\hline 579 & 13633.65 & 94.82 \\
\hline 578 & 13539.7 & 93.95 \\
\hline 577 & 13446.65 & 93.04 \\
\hline 576 & 13354.55 & 92.11 \\
\hline 575 & 13263.4 & 91.14 \\
\hline 574 & 13173.25 & 90.16 \\
\hline 573 & 13084.11 & 89.14 \\
\hline 572 & 12996.01 & 88.10 \\
\hline 571 & 12908.98 & 87.03 \\
\hline 570 & 12823.03 & 85.94 \\
\hline 569 & 12738.2 & 84.83 \\
\hline 568 & 12654.5 & 83.70 \\
\hline 567 & 12571.95 & 82.55 \\
\hline 566 & 12490.58 & 81.37 \\
\hline 565 & 12410.4 & 80.18 \\
\hline 564 & 12331.43 & 78.97 \\
\hline 563 & 12253.69 & 77.74 \\
\hline 562 & 12177.19 & 76.50 \\
\hline 561 & 12101.95 & 75.24 \\
\hline 560 & 12027.99 & 73.97 \\
\hline 559 & 11955.31 & 72.68 \\
\hline 558 & 11883.93 & 71.38 \\
\hline 557 & 11813.86 & 70.07 \\
\hline 556 & 11745.12 & 68.74 \\
\hline 555 & 11677.71 & 67.41 \\
\hline 554 & 11611.64 & 66.07 \\
\hline 553 & 11546.92 & 64.72 \\
\hline 552 & 11483.56 & 63.36 \\
\hline 551 & 11421.57 & 62.00 \\
\hline 550 & 11360.94 & 60.63 \\
\hline 549 & 11301.69 & 59.25 \\
\hline 548 & 11243.81 & 57.88 \\
\hline 547 & 11187.31 & 56.50 \\
\hline 546 & 11132.2 & 55.11 \\
\hline 545 & 11078.47 & 53.73 \\
\hline 544 & 11026.13 & 52.35 \\
\hline 543 & 10975.16 & 50.96 \\
\hline 542 & 10925.58 & 49.58 \\
\hline 541 & 10877.38 & 48.20 \\
\hline 540 & 10830.56 & 46.83 \\
\hline 539 & 10785.1 & 45.46 \\
\hline 538 & 10741.01 & 44.09 \\
\hline 537 & 10698.72 & 42.29 \\
\hline 536 & 10658.23 & 40.49 \\
\hline 535 & 10619.54 & 38.69 \\
\hline & & \\
\hline & \\
\hline
\end{tabular}

\begin{tabular}{|c|c|c|}
\hline $\begin{array}{c}\text { Depth } \\
\text { (cm) }\end{array}$ & $\begin{array}{c}\text { Age } \\
\text { (cal yr BP) }\end{array}$ & $\begin{array}{c}\text { SAR } \\
\text { (yr } \mathrm{cm}^{-1} \text { ) }\end{array}$ \\
\hline 534 & 10582.65 & 36.89 \\
\hline 533 & 10547.56 & 35.09 \\
\hline 532 & 10514.27 & 33.29 \\
\hline 531 & 10482.78 & 31.49 \\
\hline 530 & 10453.09 & 29.69 \\
\hline 529 & 10425.2 & 27.89 \\
\hline 528 & 10399.11 & 26.09 \\
\hline 527 & 10374.83 & 24.29 \\
\hline 526 & 10352.34 & 22.49 \\
\hline 525 & 10331.65 & 20.69 \\
\hline 524 & 10312.76 & 18.89 \\
\hline 523 & 10295.67 & 17.09 \\
\hline 522 & 10280.38 & 15.29 \\
\hline 521 & 10268 & 12.38 \\
\hline 520 & 10256 & 12.00 \\
\hline 519 & 10240 & 16.00 \\
\hline 518 & 10224 & 16.00 \\
\hline 517 & 10209 & 15.00 \\
\hline 516 & 10193 & 16.00 \\
\hline 515 & 10177 & 16.00 \\
\hline 514 & 10161 & 16.00 \\
\hline 513 & 10145 & 16.00 \\
\hline 512 & 10130 & 15.00 \\
\hline 511 & 10114 & 16.00 \\
\hline 510 & 10098 & 16.00 \\
\hline 509 & 10082 & 16.00 \\
\hline 508 & 10066 & 16.00 \\
\hline 507 & 10051 & 15.00 \\
\hline 506 & 10035 & 16.00 \\
\hline 505 & 10019 & 16.00 \\
\hline 504 & 10003 & 16.00 \\
\hline 503 & 9987 & 16.00 \\
\hline 502 & 9972 & 15.00 \\
\hline 501 & 9956 & 16.00 \\
\hline 497.96 & 9908 & 15.79 \\
\hline 493.88 & 9843 & 15.93 \\
\hline 489.8 & 9779 & 15.69 \\
\hline 485.71 & 9714 & 15.89 \\
\hline 481.63 & 9650 & 15.69 \\
\hline 477.55 & 9585 & 15.93 \\
\hline 473.47 & 9521 & 15.69 \\
\hline 469.39 & 9456 & 15.93 \\
\hline 465.31 & 9392 & 15.69 \\
\hline 461.22 & 9327 & 15.89 \\
\hline 457.14 & 9263 & 15.69 \\
\hline 453.06 & 9198 & 15.93 \\
\hline 448.98 & 9132 & 16.18 \\
\hline 444.9 & 9051 & 19.85 \\
\hline 440.82 & 8970 & 19.85 \\
\hline 436.73 & 8889 & 19.80 \\
\hline 432.65 & 8808 & 19.85 \\
\hline 428.57 & 8727 & 19.85 \\
\hline 424.49 & 8646 & 19.85 \\
\hline 420.41 & 8565 & 19.85 \\
\hline 416.33 & 8484 & 19.85 \\
\hline 412.24 & 8403 & 19.80 \\
\hline 408.16 & 8322 & 19.85 \\
\hline 404.08 & 8241 & 19.85 \\
\hline 401.02 & 8181 & 19.61 \\
\hline 397.87 & 8118 & 20.00 \\
\hline 393.62 & 8034 & 19.76 \\
\hline 389.36 & 7949 & 19.95 \\
\hline 385.11 & 7865 & 19.76 \\
\hline 380.85 & 7781 & 19.72 \\
\hline 376.6 & 7696 & 20.00 \\
\hline 372.34 & 7612 & 19.72 \\
\hline & & \\
\hline
\end{tabular}

\begin{tabular}{|c|c|c|}
\hline $\begin{array}{c}\text { Depth } \\
\text { (cm) }\end{array}$ & $\begin{array}{c}\text { Age } \\
\text { (cal yr BP) }\end{array}$ & $\begin{array}{c}\text { SAR } \\
\left(\mathrm{yr}^{-1} \text { ) }\right.\end{array}$ \\
\hline 368.09 & 7527 & 20.00 \\
\hline 363.83 & 7443 & 19.72 \\
\hline 359.57 & 7359 & 19.72 \\
\hline 355.32 & 7274 & 20.00 \\
\hline 351.06 & 7136 & 32.39 \\
\hline 346.81 & 6985 & 35.53 \\
\hline 342.55 & 6834 & 35.45 \\
\hline 338.3 & 6683 & 35.53 \\
\hline 334.04 & 6532 & 35.45 \\
\hline 329.79 & 6381 & 35.53 \\
\hline 325.53 & 6230 & 35.45 \\
\hline 321.28 & 6079 & 35.53 \\
\hline 317.02 & 5928 & 35.45 \\
\hline 312.77 & 5781 & 34.59 \\
\hline 308.51 & 5639 & 33.33 \\
\hline 304.26 & 5497 & 33.41 \\
\hline 301.06 & 5390 & 33.44 \\
\hline 298.4 & 5301 & 33.46 \\
\hline 294.12 & 5158 & 33.41 \\
\hline 289.84 & 5015 & 33.41 \\
\hline 285.56 & 4873 & 33.18 \\
\hline 281.28 & 4730 & 33.41 \\
\hline 277.01 & 4587 & 33.49 \\
\hline 272.73 & 4444 & 33.41 \\
\hline 268.45 & 4301 & 33.41 \\
\hline 264.17 & 4158 & 33.41 \\
\hline 259.89 & 4015 & 33.41 \\
\hline 255.61 & 3873 & 33.18 \\
\hline 251.34 & 3730 & 33.49 \\
\hline 247.06 & 3587 & 33.41 \\
\hline 242.78 & 3444 & 33.41 \\
\hline 238.5 & 3301 & 33.41 \\
\hline 234.22 & 3212 & 20.79 \\
\hline 229.95 & 3122 & 21.08 \\
\hline 225.67 & 3033 & 20.79 \\
\hline 221.39 & 2944 & 20.79 \\
\hline 217.11 & 2855 & 20.79 \\
\hline 212.83 & 2765 & 21.03 \\
\hline 208.56 & 2676 & 20.84 \\
\hline 204.28 & 2587 & 20.79 \\
\hline 201.07 & 2520 & 20.87 \\
\hline 196.86 & 2432 & 20.90 \\
\hline 192.29 & 2336 & 21.01 \\
\hline 187.71 & 2241 & 20.74 \\
\hline 183.14 & 2146 & 20.79 \\
\hline 178.57 & 2050 & 21.01 \\
\hline 174 & 1955 & 20.79 \\
\hline 169.43 & 1859 & 21.01 \\
\hline 164.86 & 1764 & 20.79 \\
\hline 160.29 & 1668 & 21.01 \\
\hline 155.71 & 1516.364 & 33.11 \\
\hline 151.14 & 1364.727 & 33.18 \\
\hline 146.57 & 1213.091 & 33.18 \\
\hline 142 & 1061.455 & 33.18 \\
\hline 137.43 & 909.8182 & 33.18 \\
\hline 132.86 & 758.1818 & 33.18 \\
\hline 128.29 & 606.5455 & 33.18 \\
\hline 123.71 & 454.9091 & 33.11 \\
\hline 119.14 & 303.2727 & 33.18 \\
\hline 114.57 & 151.6364 & 33.18 \\
\hline 111.14 & 0 & 44.21 \\
\hline & & \\
\hline
\end{tabular}




\section{References}

Bennett, K.D. 2005: Psimpoll Manual. http://chrono.qub.ac.uk/psimpoll/psimpoll.html

Bennett, K.D., J.L. Fuller 2002: Determining the age of the mid-Holocene Tsuga canadensis (hemlock) decline, eastern North America. - The Holocene 12, pp. 421-429.

Björck, S., M.J.C. Walker, L.C. Cwynar, S. Johnsen, K.L. Knudsen, J.J. Lowe, B. Wohlfarth, INTIMATE members 1998: An event stratigraphy for the Last Termination in the North Atlantic region based on the Greenland ice-core record: a proposal by the INTIMATE group. - Journal of Quaternary Science, 13, pp. 283-292.

Buck, C.E., J.A. Christen, G.N. James 1999: BCal: an on-line Bayesian radiocarbon calibration tool. Internet Archaeology, 7 (http://intarch.ac.uk/journal/issue7/buck/).

Buczkó, K., E.K. Magyari, M. Braun, M. Bálint 2009: Late Glacial and Holocene diatoms from glacial lake Taul dintre Brazi, Retezat Mts., Romania. - In: Lotter, A., H. Cremer, M. Mullen, R. Vasiliauskiené, H. Hooghart (Ed.): The joint 40th Meeting of the Dutch-Flemish Society of Diatomists (NVKD) and 3rd Central European Diatom Meeting (CE-DiatoM). Utrecht, Hollandia, 2009.03.26-2009.03.29. pp. 36-39. (Diatomededelingen 33)

Buczkó, K., E.K. Magyari, É. Soróczki-Pintér, K. Hubay, M. Braun, M. Bálint 2010: Diatom-based evidence for abrupt climate changes during the Late Glacial in the Southern Carpathian Mountains. - Central European Geology, 52, pp. 249-268.

Cleveland, W.S., S.J. Devlin 1988: Locally weighted regression: an approach to regression analysis by local fitting. - Journal of the American Statistical Association 83, pp. 596-610.

Constantin, S., A.V. Bojar, S.-E. Lauritzen, J. Lundberg 2007: Holocene and Late Pleistocene climate in the sub-Mediterranean continental environment: A speleothem record from Poleva Cave (Southern Carpathians, Romania). - Palaeogeography, Palaeoclimatology, Palaeoecology 243, pp. 322-338.

Emery, G.R., D.E. Broussard 1954: A modified Kullenberg piston corer. - Journal of Sedimentary Petrology, 24, pp. 207-211.

Farcas S., J.L. de Beaulieu, M. Reille, G. Coldea, B. Diaconeasa, C. Goeury, T. Goslar, T. Jull 1999: First ${ }^{14} \mathrm{C}$ dating of Late Glacial and Holocene pollen sequences from the Romanian Carpathians. Comptes Rendues de l'Académie des Sciences de Paris, Sciences de la Vie, 322, pp. 799-807.

Feurdean, A., O. Bennike 2004: Late Quaternary palaeoecological and paleoclimatological reconstruction in the Gutaiului Mountains, NW Romania. - Journal of Quaternary Science 19, pp. 809-827.

Feurdean, A., B. Wohlfarth, L. Björkman, I. Tantau, O. Bennike, K.J. Willis, S. Farcas, A.M. Robertsson 2007: The influence of refugial population on Late Glacial and early Holocene vegetational changes in Romania. - Review of Palaeobotany and Palynology, 145, pp. 305-320.

Gehrig, R. 1997: Pollenanalytische Untersuchungen zur Vegetations- und Klimageschichte des Val Camonica (Norditalien). - Dissertationes botanicae, 276, pp. 1-152.

Gobet, E., W. Tinner, P.A. Hochuli, J.F.N. van Leeuwen, B. Ammann 2003: Middle to late Holocene vegetation history of the Upper Engadine (Swiss Alps): the role of man and fire. - Vegetation History and Archaeobotany 12, pp. 143-163.

Heiri, O., A.F. Lotter, G. Lemcke 2001: Loss on ignition as a method for estimating organic and carbonate content in sediments: reproducibility and comparability of results. - Journal of Paleolimnology, 25, pp. 101-110.

Heiss, A.G., W. Kofler, K. Oeggl 2005: The Ulten Valley in South Tyrol, Italy: Vegetation and Settlement History of the Area, and Macrofossil Record from the Iron Age Cult Site of St. Walburg. - Palyno-Bulletin of the Institute of Botany, University of Innsbruck, 1-2, pp. 63-73.

Hubay, K., M. Braun, I. Papp, S. Harangi, Sz. Struba, E.K. Magyari 2010: Late Glacial climate-driven soil and environment changes in the South Carpathian Mountains recorded by sediment geochemistry. - in press.

Huybers, P. 2006: Early Pleistocene Glacial Cycles and the Integrated Summer Insolation Forcing. Science 313(5786), pp. 508-511. 
Ilyashuk, B., E. Gobet, O. Heiri, A.F. Lotter, J.F.N. van Leeuwen, W.O. van der Knaap, E. Ilyashuk, F. Oberli, B. Ammann 2009: Late Glacial environmental and climatic changes at the Maloja Pass, Central Swiss Alps, as recorded by chironomids and pollen. - Quaternary Science Reviews, 28, pp. 1340-1353.

Jancsik, P. 2001: A Retyezát-hegység (The Retezat Mountains). - Pallas-Akadémia Könyvkiadó, Csíkszereda, $140 \mathrm{p}$.

Kaltenrieder P., C.A. Belis, S. Hofstetter, B. Ammann, C. Ravazzi, W. Tinner 2009: Environmental and climatic conditions at a potential Glacial refugial site of tree species near the Southern Alpine glaciers. New insights from multiproxy sedimentary studies at Lago della Costa (Euganean Hills, Northeastern Italy). - Quaternary Science Reviews, 28, pp. 2647-2662.

Kern, Z., D. Balogh, B. Nagy 2004: Investigations for the actual elevation of the mountain permafrost zone on postglacial landforms in the head of Lapusnicu Mare Valley, and the history of deglaciation of Ana Lake - Judele Peak region, Retezat Mountains, Romania. Analele Universitatii de Vest din Timisoara, GEOGRAFIE, 14, pp. 119-132.

Lotter, A.F., H.J.B. Birks 2003: The Holocene palaeolimnology of Sägistalsee and its environmental history - a synthesis. - Journal of Paleolimnology, 30, pp. 333-342.

Lotter, A. F., C. Bigler 2000: Do diatoms in the Swiss Alps reflect the length of ice-cover? - Aquatic Sciences, 62, pp. 125-141.

Lotter, A., R. Pienitz, R. Schmidt 2001: Diatoms as indicators of environmental change near arctic and alpine tree line. In: Stoermer, E.F., J.P. Smol (eds): The Diatoms: Application for the Environmental and Earth Sciences, Cambridge University Press. pp. 205-226.

Lupsa, V. 1968: Die Pollenanalyse der Alpinen Böden im Nationalpark Retezat. - Ocrotirea Naturii, 12/2, pp. 203-210.

Magny, M., J.N. Haas 2004: A major widespread climatic change around $5300 \mathrm{cal}$. yr BP at the time of the Alpine Iceman. - Journal of Quaternary Science, 19/5, pp. 423-430.

Magyari, E.K., K. Buczkó, G. Jakab, M. Braun, Zs. Szántó, M. Molnár, Z. Pál, D. Karátson 2006: Holocene palaeohydrology and environmental history in the South Harghita Mountains, Romania. - Földtani Közlöny, 136/2, pp. 249-284.

Magyari, E., G. Jakab, M. Braun, K. Buczkó, M. Bálint 2009a: High-resolution study of Late Glacial and Early Holocene tree line changes in the Southern Carpathian Mountains. - Geophysical Research Abstracts, 11, p. 10549.

Magyari, E.K., K. Buczkó, G. Jakab, M. Braun, Z. Pál, D. Karátson 2009b: Palaeolimnology of the last crater lake in the Eastern Carpathian Mountains - a multiproxy study of Holocene hydrological changes. - Hydrobiologia, 631, pp. 29-63.

Magyari, E.K., G. Jakab, M. Braun, K. Buczkó, M. Bálint: Rapid responses of high-mountain vegetation to Late Glacial and Early Holocene climatic oscillations - a case study from the South Carpathian Mountains, Romania. in prep.

Mook, W.G., H.J. Streurman 1983: Physical and chemical aspects of radiocarbon dating. - PACT Publications 8, pp. 31-55.

Moore, P.D., J.A. Webb, M.E. Collinson 1992: Pollen analysis. Second edition. - Blackwell Scientific Publications, Oxford.

Nyárádi, E.I. 1958: Flora si vegetatia Muntilor Retezat. - Bucharest.

Pop, E., V. Lupsa, N. Boscaiu 1971: Diagrama sporo-polinica de la Taul Zanogutii (Muntii Retezat). Progrese in palinologia romanesca, Acad. R.S.R. Bucharest, pp. 219-225.

Posea, G. 2002: Geomorfologica Romaniei. Editura Fundatiei Romania de Maine, Bucuresti, 444 p.

Reimer, P.., M.G.L. Baillie, E. Bard, A. Bayliss, J.W. Beck, P.G. Blackwell, C. Bronk Ramsey, C.E. Buck, G.S. Burr, R.L. Edwards, M. Friedrich, P.M. Grootes, T.P. Guilderson, I. Hajdas, T.J. Heaton, A. G. Hogg, K.A. Hughen, K.F. Kaiser, B. Kromer, F.G. McCormac, S.W. Manning, R.W. Reimer, D.A. Richards, J.R. Southon, S. Talamo, C. Turney, J. van der Plicht, C.E. Weyhenmeyer 2009: IntCa109 and Marine09 radiocarbon age calibration curves, 0-50,000 years cal BP. - Radiocarbon, 51/4, pp. 1111-50. 
Reuther, A.U., P. Urdea, C. Geiger, S. Ivy-Ochs, H.P. Niller, P.W. Kubik, K. Heine 2007: Late Pleistocene glacial chronology of the Pietrele Valley, Retezat Mountains, Southern Carpathians constrained by $10 \mathrm{Be}$ exposure ages and pedological investigations. - Quaternary International, 164-65, pp. 151-169.

Schomacker, A. 2008: What controls dead-ice melting under different climate conditions? A discussion. - Earth-Science Reviews, 90, pp. 103-113.

Takeuchi, Y., R.B. Kayashta, M. Nakawo 2000: Characteristics of ablation and heat balance in debrisfree and debris-covered areas on Khumbu Glacier, Nepal Himalayas, in the pre-monsoon season. - IAHS Publication, 264, pp. 53-61.

Tinner, W., J.-P. Theurillat 2003: Uppermost limit, extent and fluctuations of the timberline ecotone in the Swiss Central Alps during the past 11500 years. - Arctic, Antarctic Alpine Research, 35, pp. $158-169$.

Troels-Smith, J. 1955: Karakterisering af lose jordater. - Danmarks Geologiske Undersogelse, ser. IV, 10, pp. 1-53.

Urdea, P. 1993: Consideratii asupra manifestarii glaciatiei cuaternare in Muntii Retezat. - Studii si cercetari de geografie 60, pp. 65-72.

Urdea, P. 2000: Muntii Retezat. Studiu geomorphologic. - Editura Academiei, Bucuresti, 272 p.

Urdea, P. 2001: Glaciar relief and Pleistocene glaciation in Retezat Mountains (Transylvanians Alps, Romania). - Geographica Pannonica, 5, pp. 4-7.

Urdea, P. 2004: The Pleistocene glaciation of the Romanian Carpathians. - In: Ehlers, J., P.L. Gibbard (Eds): Quaternary Glaciations-Extent and Chronology, Part I, pp. 301-308.

Vescovi, E., C. Ravazzi, E. Arpenti, W. Finsinger, R. Pini, V. Valsecchi, L. Wick, B. Ammann, W. Tinner 2007: Interactions between climate and vegetation during the Late Glacial period as recorded by lake and mire sediment archives in Northern Italy and Southern Switzerland. - Quaternary Science Reviews, 26, pp. 1650-1669.

Walker, M. 2005: Quaternary dating methods. - John Wiley and Sons Ltd, Chichester.

Wanner, H., J. Beer, J. Bütikofer, TJ. Crowley, U. Cubasch, J. Flückiger, H. Goosse, M. Grosjean, F. Joos, J.O. Kaplan, M. Küttel, S.A. Müller, I.C. Prentice, O. Solomina, T.F. Stocker, P. Tarasov, M. Wagner, M. Widmann 2008: Mid- to Late Holocene climate change: an overview. - Quaternary Science Reviews, 27/19-20, pp. 1791-1828.

Wohlfarth, B., G. Hannon, A. Feurdean, L. Ghergari, B.P. Onac, G. Possnert 2001: Reconstruction of climatic and environmental changes in NW Romania during the early part of the last deglaciation (15,000-13,600 cal years BP). - Quaternary Science Reviews 20, pp. 1897-1914.

Zoller, H., H. Kleiber 1971: Vegetationsgeschichtliche Untersuchungen in der montanen und subalpinen Stufe der Tessintaler. - Verhandlungen der Naturforschenden Gesellschaft in Basel 81, pp. 90-153. 